\title{
ISSN 2088-1045
}

\section{Jurnal \\ Volume 5 | Nomor 1 | April 2019 \\ PENERAPAN REKRUTMEN DAN PELATIHAN GURU SEKOLAH MINGGU DI GBI METRO PERMATA}

\author{
Yohanes Siagian - yohannessiagian245@gmail.com \\ Andreas Eko Nugroho - andreasnugroho68@gmail.com* \\ *Dosen Teologi STTB The Way
}

\begin{abstract}
Abstrak
Penelitian ini bertujuan mengkaji pentingnya pelaksanaan rekrutmen sumber daya manusia (SDM) yang menjadi bagian dari pelayan di GBI Metro Permata dan memberikan masukkan yang konstruktif terhadap pelayanan Sekolah Minggu melalui ketersediaan tenaga pelayan, cara pelatihan dan kesinambungan pelayanan S.M. di GBI Metro Permata. Penelitian ini menggunakan metode Studi Pustaka dan Metode Penelitian Kualitatif Analisis Deskriptif. Analisis data dalam penelitian kualitatif menggunakan analisis data secara induktif. Data yang dikumpulkan berupa wawancara dan catatan lapangan. Dalam penelaahan teks Alkitab menggunakan Studi Biblika. Studi Biblika menggunakan pembahasan teks-teks Alkitab dengan prinsip-prinsip atau metode eksposisi. Dari hasil penelitian ini didapatkan bahwa proses rekrutmen yang dilakukan harus memperhatikan kualifikasi yang ditetapkan oleh gereja. pada akhirnya gereja dapat menemukan pelayan guru S.M. yang berkompeten dan berkualitas. Kegiatan pelayanan yang dilakukan oleh guru-guru S.M. dapat berjalan efektif dan sistematis, sehingga didapatkan guru-guru S.M. yang berkompeten dan berkomitmen dalam melakukan pelayanannya.Kesimpulannya, pada teori-teori mengenai rekrutmen harus memiliki peranan, tujuan, sumber, kualifikasi dan proses dalam melakukan rekrutmen. Penting bagi sebuah organisasi terutama sebuah gereja untuk memiliki program pelatihan bagi setiap bidang atau kategorial pelayanannya. Teori-teori mengenai guru S.M. yang telah dikemukakan oleh para ahli bahwa sejarah berdirinya S.M. dimulai pada abad ke18, untuk menjadi guru S.M. juga harus memiliki syarat dan batasan umur. Agar didapatkan guruguru S.M. yang berkompeten dan berkomitmen dalam pelayanannya.
\end{abstract}

Kata Kunci: Rekrutmen, Guru, Sekolah Minggu, Alkitab.

This study aims to examine the importance of the recruitment of human resources (HR) who are part of the servants at GBI Metro Permata and provide constructive input to Sunday School services through the availability of servants, training methods and continuity of the service of S.M. at GBI Metro Permata. This study uses the method of Library Studies and Qualitative Research Methods Descriptive Analysis. Data analysis in qualitative research uses inductive data analysis. Data collected in the form of interviews and field notes. In the study of the biblical text using Biblical Studies. Biblical Studies uses the discussion of biblical texts with exposition principles or methods. From the results of this study it was found that the recruitment process carried out must pay attention to the qualifications set by the church. Finally the church could find the teacher of S.M. competent and qualified. Service activities carried out by teachers of S.M. can run effectively and systematically, so that the teachers obtained S.M. who are competent and committed to doing their services. In conclusion, the theories regarding recruitment must have a role, goals, resources, qualifications and processes for recruiting. It is important for an organization, especially a church, to have a training program for each field or categorical ministry. Theories about teacher S.M. which 
has been stated by experts that the history of the establishment of S.M. began in the 18th century, to become a teacher of S.M. must also have terms and conditions for age. In order to get the teachers of S.M. who are competent and committed to their service.

Keywords: Recruitment, Teacher, Sunday School, Bible.

\section{Pendahuluan}

Sebelum Tuhan Yesus hendak naik ke Surga, la memberikan mandat kepada murid-murid-Nya untuk pergi dan menjadikan semua bangsa murid-Nya (Mat. 28: 19-20). Mandat ini menjadi tugas dan tanggung jawab setiap orang percaya. Melalui isi dari mandat ini dapat dipahami bahwa frase menjadikan semua bangsa murid-Ku terkait dengan semua, dari segala suku bangsa dan dari semua tingkatan umur, baik orang dewasa maupun anak-anak, melalui usaha dari gereja untuk mengajar dan mendidik mereka kepada pengenalan akan Tuhan supaya sudah ditekankan. Hal mendidik sebenarnya sudah ditekankan dalam Amsal 22:6, yakni "didiklah orang muda menurut jalan yang patut baginya, maka pada masa tuanya pun ia tidak akan menyimpang dari pada jalan itu". Hubungan antara didikan dan masa depan sangat jelas disebutkan pada ayat diatas termasuk bagi anak-anak. Atas dasar inilah gereja sudah semestinya memberikan perhatian ekstra untuk ikut ambil bagian dalam memberikan didikan rohani kepada anakanak melalui pelayanan kategorial atau bidang yang dinamakan Sekolah Minggu. Didikan rohani yang diberikan kepada anak-anak di gereja merupakan sebuah panggilan pelayanan yang mulia.

Sekolah Minggu ini dikelola layaknya sekolah formal meskipun penekanannya kepada kebaktian, yang diperlengkapi dengan bahan ajaran, pengajar dan pembagian kelas berdasarkan kategori umur anak. Bagian yang tidak kalah pentingnya di dalam pelayanan kategorial ini adalah pengajar atau guru Sekolah Minggu. Guru Sekolah Minggu tentunya merupakan orang-orang yang berkompeten, bukan hanya orang yang hanya ingin mengisi waktu luangnya di hari Minggu tetapi merupakan orang yang benar-benar terpanggil dan mau mempelajari firman Tuhan untuk diajarkan kembali kepada anak-anak sekolah minggu. Pendidikan terhadap anak-anak sangatlah penting karena akan memengaruhi kehidupan mereka pada saat dewasa nanti. Tidak hanya itu, anakanak adalah sebagai penerus atau generasi yang akan mewarisi gereja dan bangsa kelak. Begitu juga di dalam gereja, anak-anak adalah pelaku-pelaku yang akan menjalankan suatu gereja dan meneruskan pemberitaan Injil mengenai Yesus Kristus. Perlu diketahui oleh seorang pengajar atau guru Sekolah Minggu, bahwa perannya bukan hanya untuk menjaga anak pada saat orangtua mereka sedang beribadah, sehingga demi menghindari terjadinya gangguan dalam ibadah. Peran guru Sekolah Minggu justru sangat penting dalam pembimbingan dan pendidikan kerohanian anak-anak Sekolah Minggu, supaya pertumbuhan iman anak-anak itu berkesinambungan guna mempersiapkan mereka untuk menjadi pemimpin-pemimpin Kristen dalam memberitakan Injil mengenai Yesus Kristus di muka bumi, baik dalam konteks gereja maupun konteks berbangsa dan bernegara.

Gereja pada umumnya dan pada khususnya di GBI Metro Permata perlu memikirkan cara rekrutmennya untuk mendukung dan memfasilitasi animo anakanak muda di GBI Metro Permata dalam kerinduan mereka melayani sebagai guru Sekolah Minggu. Gambaran umum, di GBI Metro Permata merespon pelayanan 
Sekolah Minggu dengan cara melakukan pembagian kelas, usia, waktu dalam pelayanan Minggu. Sekolah Minggu di GBI Metro Permata terbagi menjadi tiga kelas. Kelas Balita, kelas Pratama, dan kelas Madya. Kelas Balita berisikan anakanak yang berusia dari $0-6$ tahun, kelas Pratama berisikan anak-anak yang berusia 7 - 9 tahun dan kelas Madya berisikan anak-anak yang berusia $10-12$ tahun. Berdasarkan pembagian kelas yang dilakukan di GBI Metro Permata maka disetiap kelas diharuskan terdapat setidaknya 2 orang guru Sekolah Minggu yang dapat berfungsi sebagai wali atau kakak-kakak yang bertanggung jawab untuk memantau kerohanian setiap anak-anak didiknya.

Permasalahan yang terdapat dipelayanan kategorial atau bidang Sekolah Minggu pada guru-guru yang masih pelajar Sekolah Menengah Pertama (SMP) dan Sekolah Menengah Atas (SMA) tidak hanya sampai kehadiran mereka yang datang terlambat saja, namun kehadiran mereka pada waktu melayani di Sekolah Minggu tidak langsung menangani anak-anaknya, melainkan mereka lebih fokus dengan telepon genggamnya, foto barsama dengan sesama guru-guru yang seusianya, mendengarkan dan menyanyikan lagu-lagu populer yang ada ditelepon genggamnya. Sebaliknya kehadiran guru-guru berusia diatas 21 tahun, langsung memperhatikan kepada anggota jemaat Sekolah Minggu, sehingga kebanyakan dari guru-guru Sekolah Minggu yang berusia diatas 21 tahun kehadirannya selalu ditunggu dan dinanti-nantikan oleh jemaat Sekolah Minggu. Dalam hal mengajarkan atau menyampaikan Firman Tuhan bagi semua guru-guru Sekolah Minggu yang ada di GBI Metro Permata diharapkan bisa untuk mengajar Firman Tuhan. Mereka menyampaikan Firman Tuhan berdasarkan bahan ajar yang telah ditetapkan oleh gembala dan diambil dari buku panduan pelayan Firman kebaktian anak, yakni 'Benih Kekal' sebagai buku pedoman mengajar di GBI Metro Permata. Buku panduan itu juga dilakukan bagi guru-guru Sekolah Minggu yang masih pelajar Sekolah Menengah Pertama dan Sekolah Menegah Atas. Semua guruguru Sekolah Minggu diminta oleh gembala untuk mempersiapkan bahan pengajarannya jauh-jauh hari, sesuai dengan tema yang akan mereka sampaikan. Tidak hanya sampai pada persiapan saja, gembala juga meminta agar semua guru-guru Sekolah Minggu mengembangkan setiap pengajarannya dari buku yang menjadi pedoman dalam hal mengajar. Semua guru-guru Sekolah Minggu diminta untuk membaca Firman Tuhan setiap hari yang sifatnya wajib oleh gembala di GBI Metro Permata.

Berdasarkan uraian tersebut, terlihat perbedaan cara berpikir dan cara bertanggung jawab antara guru Sekolah Minggu pelajar Sekolah Menengah Pertama dan Sekolah Menengah Atas, serta guru-guru yang berusia diatas 21 tahun dengan masalah-masalah yang dialami, maka jelas sudah seharusnya mereka tidak dahulu dimasukkan ke dalam team pengajaran Sekolah Minggu terutama di GBI Metro Permata hal ini dikarenakan mereka masih membutuhkan pertolongan dan bimbingan dari orang-orang dewasa, sedangkan mereka ingin membimbing anak-anak yang usianya tidak terpaut jauh dari mereka dengan pengalaman hidup yang mereka miliki masih sedikit, namun sudah tentu gereja tidak dapat menahan potensi mereka untuk berkembang, terutama dalam mengambil kesempatan untuk melayani Tuhan di ladang-Nya, sebab di dalam 2 Timotius 3:16 mengatakan: "Segala tulisan yang diilhamkan Allah memang bermanfaat untuk mengajar, untuk menyatakan kesalahan, untuk memperbaiki kelakuan dan untuk mendidik orang dalam kebenaran”. Belum lagi GBI Metro 
Permata kekurangan pelayan yang mau melayani dalam bidang atau kategorial Sekolah Minggu, mengingat jumlah dari jemaat Sekolah Minggu yang cukup banyak, sehingga memerlukan pelayan atau guru-guru Sekolah Minggu yang cukup sesuai dengan jumlah jemaat dari Sekolah Minggu di GBI Metro Permata.

Rumusan Masalah

Berdasarkan pembatasan masalah di atas, maka di bawah ini penulis membuat rumusan masalah, yaitu:

1. Bagaimana pelaksanaan rekrutmen guru Sekolah Minggu di GBI Metro Permata?

2. Bagaimana pelatihan yang telah dilakukan di GBI Metro Permata untuk guru Sekolah Minggu?

\section{Metode Penelitian}

Dalam penelitian ini penulis menggunakan Studi Pustaka dan Metode Penelitian Kualitatif Analisis Deskriptif. Analisis data dalam penelitian kualitatif menggunakan analisis data secara induktif, analisis data secara induktif ini digunakan karena beberapa alasan. Pertama, proses induktif lebih dapat menemukan kenyataan-kenyataan jamak sebagai yang terdapat dalam data. Kedua, analisis induktif lebih dapat membuat hubungan peneliti-responden menjadi eksplisit, dapat dikenal dan akuntable. Ketiga, analisis demikian lebih dapat menguraikan latar secara penuh dan dapat membuat keputusan-keputusan tentang dapat-tidaknya pengalihan pada suatu latar lainnya. Keempat, analisis induktif lebih dapat menemukan pengaruh bersama yang mempertajam hubungan-hubungan. Kelima, analisis demikian dapat memperhitungkan nilai-nalai secara eksplisit sebagai bagian dari struktur analitik. Data yang dikumpulkan berupa wawancara dan catatan lapangan, sedangkan dalam wawancara peneliti menggunakan pertanyaan dengan kata tanya mengapa, alasan apa dan bagaimana terjadinya yang akan senantiasa digunakan dan dimanfaatkan oleh peneliti. ${ }^{1}$ Dalam penelaahan teks Alkitab yang digunakan dalam kajian penelitian ini akan menggunakan studi Biblika. Studi Biblika adalah menggunakan pembahasan teks-teks Alkitab dengan prinsip-prinsip atau studi Biblika dengan metode eksposisi.

\section{Hasil Penelitian}

Penelitian ini memaparkan Peranan Rekrutmen dan Pelatihan Guru Sekolah Minggu di GBI Metro Permata. Hasil wawancara dan analisis data dijelaskan dalam bentuk tabel dan skema. Berdasarkan hasil data lapangan berupa wawancara langsung kepada gembala, sekretariat, guru Sekolah Minggu dan orangtua dari anak Sekolah Minggu di GBI Metro Permata, maka analisis sementara dari penulis adalah sebagai berikut.

\footnotetext{
${ }^{1}$ Lexy J. Moleong, Penelitian Kualitatif (Bandung: Alfabeta, 2000), 11.
} 
Rekrutmen: Kesimpulan Wawancara dan Penerapan Mengenai Rekrutmen

\begin{tabular}{|c|c|}
\hline \multicolumn{2}{|r|}{ Rekrutmen } \\
\hline No & Jawaban \\
\hline 1 & $\begin{array}{l}\text { Rekrutmen: Secara umum penting karena rekrutmen berperan untuk mencari } \\
\text { sumber daya manusia yaitu pengerja yang berkualitas untuk mengisi Sekolah } \\
\text { Minggu diantaranya: } \\
\text { 1. Melayani Rohkris di Sekolah-sekolah } \\
\text { 2. Pemusik } \\
\text { 3. Fasilitator } \\
\text { 4. Konselor } \\
\text { 5. Pembicara }\end{array}$ \\
\hline 2 & $\begin{array}{l}\text { Tujuan rekrutmen:untuk mencari SDM yang diperlukan dengan memiliki hati } \\
\text { untuk membantu pelayanan digereja dan mau bekerja untuk suatu posisi dalam } \\
\text { Sekolah Minggu, agar memunculkan talenta yang bersangkutan lebih terampil } \\
\text { serta menyamakan visi dan misi gereja dalam pelayanan. }\end{array}$ \\
\hline 3 & $\begin{array}{l}\text { Sumber rekrutmen: } \\
\text { 1. Jemaat gereja } \\
\text { 2. Anggota youth } \\
\text { 3. Anggota rohkris } \\
\text { 4. Anggota cool }\end{array}$ \\
\hline 4 & $\begin{array}{l}\text { Kualifikasi rekrutmen: } \\
\text { 1. Kualifikasi rohani } \\
\text { 1.1. Sudah menjadi jemaat lama diatas } 2 \text { tahun } \\
\text { 1.2. Ikut KOM } 100 \\
\text { 1.3. Punya hati untuk melayani } \\
\text { 1.4. Terpanggil untuk melayani } \\
\text { 1.5. Memenuhi persyaratan rohani dan jasmani harus sehat } \\
\text { 1.6. Memenuhi syarat yang gereja lokal buat } \\
\text { 2. Kualifikasi skill } \\
\text { 2.1.Diikutkan pelatihan bagi calon guru Sekolah Minggu } \\
\text { 2.2. Memiliki kemampuan } \\
\text { 2.3. Bertalenta } \\
\text { 2.4. Skill yang dimiliki }\end{array}$ \\
\hline 5 & $\begin{array}{l}\text { Proses rekrutmen: } \\
\text { 1. Terpanggil } \\
\text { 2. Jemaat sudah } 2 \text { tahun dan terlibat aktif dalam suatu pelayanan tertentu yang } \\
\text { memberikan sumbangsih tenaga } \\
\text { 3. Jemaat menawarkan diri atau bersedia untuk membantu dalam pelayanan } \\
\text { 4. Menyampaikan kepada Ka. Bid. Sekolah Minggu } \\
\text { 5. Ka. Bid. Sekolah Minggu menyampaikan kepada gembala } \\
\text { 6. Tanyakan komitmen } \\
\text { 7. Doakan } \\
\text { 8. Pilih } \\
\text { 9. Konfirmasi kepada yang bersangkutan } \\
\text { 10. Mendapatkan persetujuan resmi gembala } \\
\text { 11. Magang }\end{array}$ \\
\hline
\end{tabular}




\section{Penerapan}

Matius 9:37-38 diyakini sebagai sebuah tanda bahwa diperlukannya tindakan untuk melakukan kegiatan rekrutmen. Pada teori-teori mengenai rekrutmen harus memiliki peranan, tujuan, sumber, kualifikasi dan proses dalam melakukan rekrutmen. Alkitab sendiri menjelaskan bahwa dalam melakukan kegiatan rekrutmen ada kualifikasinya (1 Tim. 3:1-7) dan prosesnya (Mat. 28:19-20), maka dari hasil wawancara yang telah dilakukan sebelumnya oleh penulis kepada para narasumber, didapatkan data bahwa dalam hal melakukan rekrutmen di GBI Metro Permata ada peranan, tujuan, sumber, kualifikasi dan proses rekrutmennya sendiri, sehingga penting bagi GBI Metro Permata untuk lebih memperhatikan kegiatan dalam melakukan rekrutmennya guna mencari pengerja yang berkompeten dan berkomitmen, terkhusus dibidang atau kategorial Sekolah Minggu.

Pelatihan: Kesimpulan Wawancara dan Penerapan Mengenai Pelatihan

\begin{tabular}{|c|c|}
\hline \multicolumn{2}{|r|}{ Pelatihan } \\
\hline No & Jawaban \\
\hline 1 & $\begin{array}{l}\text { Tujuan pelatihan: } \\
\text { 1. Seseorang dapat menguasai atau ahli dalam bidangnya } \\
\text { 2. Memiliki keterampilan dalam memimpin anak-anak Sekolah Minggu } \\
\text { 3. Meningkatkan SDM itu sendiri } \\
\text { 4. Menambahkan pengetahuan } \\
\text { 5. Menumbuhkan rasa tanggung jawab } \\
\text { 6. Menambahkan kecakapan dalam mengajar } \\
\text { 7. Menambah skill } \\
\text { 8. Untuk harmonisasi } \\
\text { 9. Menemukan talenta atau karunia }\end{array}$ \\
\hline 2 & $\begin{array}{l}\text { Manfaat pelatihan: } \\
\text { 1. Supaya memiliki kemampuan dalam mengajar } \\
\text { 2. Bisa memperlengkapi pengerja atau pelayan Tuhan } \\
\text { 3. Meningkatkan pengetahuan } \\
\text { 4. Membantu seseorang untuk menemukan keahlian baru } \\
\text { 5. Membuat untuk semakin kreatif dan belajar } \\
\text { 6. Mempersiapkan agar lebih efektif } \\
\text { 7. Meningkatkan kapasitas } \\
\text { 8. Agar lebih terarah, sesuai dengan visi gereja } \\
\text { 9. Melahirkan pelatih yang baru }\end{array}$ \\
\hline
\end{tabular}




\begin{tabular}{|c|c|}
\hline & $\begin{array}{l}\text { 1. Kelas KOM 100-300 } \\
\text { 2. Training cara mengajar } \\
\text { 3. Teknik sulap bagi pemula untuk menghibur anak atau pelatihan kreatifitas } \\
\text { Sekolah Minggu } \\
\text { 4. Bengkel Sekolah Minggu } \\
\text { 5. Seminar } \\
\text { 6. Musik } \\
\text { 7. Worship Leader } \\
\text { 8. Pembicara } \\
\text { 9. Doa } \\
\text { 10. Mengembalakan Cool atau rohkris } \\
\text { 11. Penyelenggaraan KKR atau RTS }\end{array}$ \\
\hline \multicolumn{2}{|r|}{ Penerapan } \\
\hline & 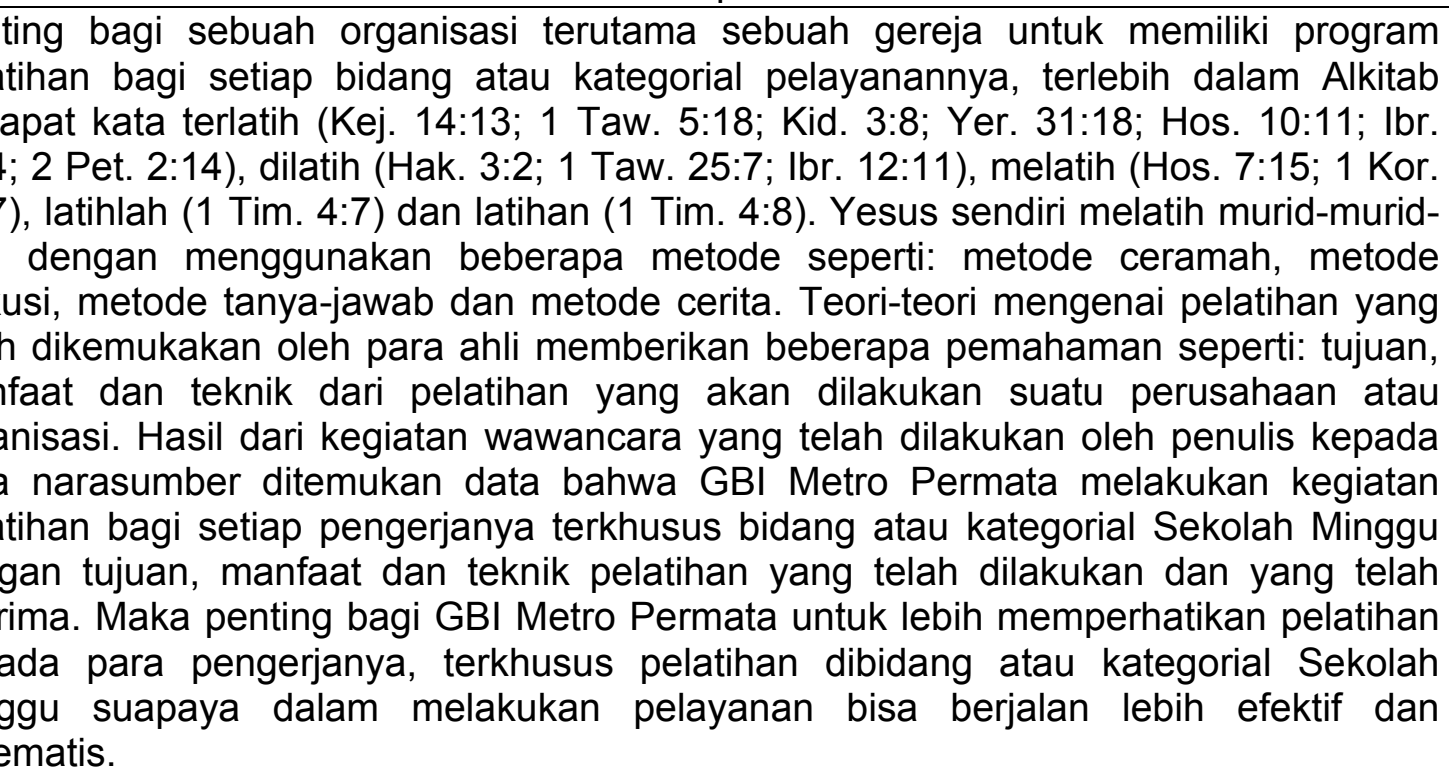 \\
\hline
\end{tabular}

Guru Sekolah Minggu: Kesimpulan Wawancara dan Penerapan Mengenai Guru Sekolah Minggu

\begin{tabular}{|l|l|}
\hline \multicolumn{1}{|c|}{ Guru Sekolah Minggu } \\
\hline No & \multicolumn{1}{|c|}{ Jawaban } \\
\hline 1 & $\begin{array}{l}\text { Sekolah Minggu sebagai wadah menampung antusias anak-anak yang masih } \\
\text { kecil untuk dididik, dilatih dan diajarkan firman Tuhan serta pujian penyembahan } \\
\text { sejak dini yang didalamnya berwujud kesukaan anak-anak yang terarah sesuai } \\
\text { dengan firman Tuhan. }\end{array}$ \\
\hline \multirow{2}{*}{2} & $\begin{array}{l}\text { Peran dari seorang guru Sekolah Minggu: } \\
\text { 1. Sebagai guru atau pengajar } \\
\text { 2. Sebagai mentor } \\
\text { 3. Sebagai fasilitator } \\
\text { 4. Sebagai pendidik } \\
\text { 5. Sebagai orangtua kedua di gereja yang tugasnya mengarahkan dan } \\
\text { mengajarkan nilai-nilai kristiani kepada anak-anak Sekolah Minggu. }\end{array}$ \\
\hline
\end{tabular}


Kebanyakan dari guru Sekolah Minggu dan orangtua tidak mengetahui Sejarah terciptanya Sekolah Minggu di GBI Metro Permata dan mengatakan bahwa gembala lebih mengetahui sejarah terciptanya guru Sekolah Minggu dan sekretariat gereja.

Sejarah Sekolah Minggu di GBI Metro Permata, menurut:

3 1. Sekertariat gereja atau fulltimer gereja: Dimulai 2001 dengan terbentuknya pos-pos penginjilan atau anak diwilayah kunciran dan pos PI yang disebut sabtu ceria di Metro Permata 1 blok a.2 no.8 dari situlah cikal bakal Sekolah Minggu mulai tumbuh dan digabungkan bersamaan dengan ibadah raya di hari Minggu (rata-rata kehadiran kurang lebih 30-50 anak)

2. Gembala: Sekolah Minggu diadakan bersamaan dengan kebaktian umum dan anak-anak dikumpulkan secara terpisah.

Untuk menjadi guru Sekolah Minggu harus memiliki syarat, diantaranya:

1. Takut akan Allah

2. Sudah dibaptis air dan Roh Kudus

3. Memiliki kelakuan yang sesuai dengan firman Tuhan

4. Menjadi anggota jemaat

5. Mengikuti KOM

4

6. Mengikuti doa pengerja

7. Sayang kepada anak-anak

8. Punya hati untuk melayani anak-anak

9. Mengerti firman Tuhan

10. Punya kesabaran yang tinggi kepada anak-anak

11. Punya kelihaian dalam me-manajemen anak-anak

12. Memiliki kemampuan untuk mengajar

Banyak tanggapan mengenai perekrutan guru Sekolah Minggu, diantaranya:

1. Gembala: Tidak ada batasan umur.

*batas atas: Merekrut orang dari berbagai level usia

*batas bawah: 16 sampai dengan 17 tahun keatas.

2. Sekertariat gereja: harus ada batasan umur minimal 17 tahun keatas, sebab 17 tahun kebawah mereka masih sering bermain dengan teman sebaya di youth atau JC sedangkan 17 tahun keatas merupakan usia memasuki "kedewasaan". Usia dibawah 17 tahun menjadi asisten guru Sekolah Minggu atau pemusik di Sekolah Minggu.

5

3. Guru Sekolah Minggu: terdapat 2 pandangan yang berbeda. Bagi Ka. Bid. Sekolah Minggu berpandangan, jika tidak ada batasan umur untuk menjadi guru Sekolah Minggu selama orang tersebut memiliki hati untuk melayani anak-anak, sedangkan bagi guru Sekolah Minggu ada batasan umur minimal sudah lulus Sekolah Menegah Atas dan tidak setuju bila umur 16 tahun menjadi guru Sekolah Minggu, karena umur 16 tahun masih susah untuk diatur.

4. Orangtua anak Sekolah Minggu: terdapat 2 pandangan yang berbeda, ada orangtua yang setuju dan yang tidak setuju. Bagi orangtua yang setuju guru Sekolah Minggu bisa berumur 16 tahun berpandangan tidak ada batasan umur untuk menjadi guru Sekolah Minggu selama dia ada panggilan. Sedangkan bagi orangtua yang tidak setuju guru Sekolah Minggu berumur 


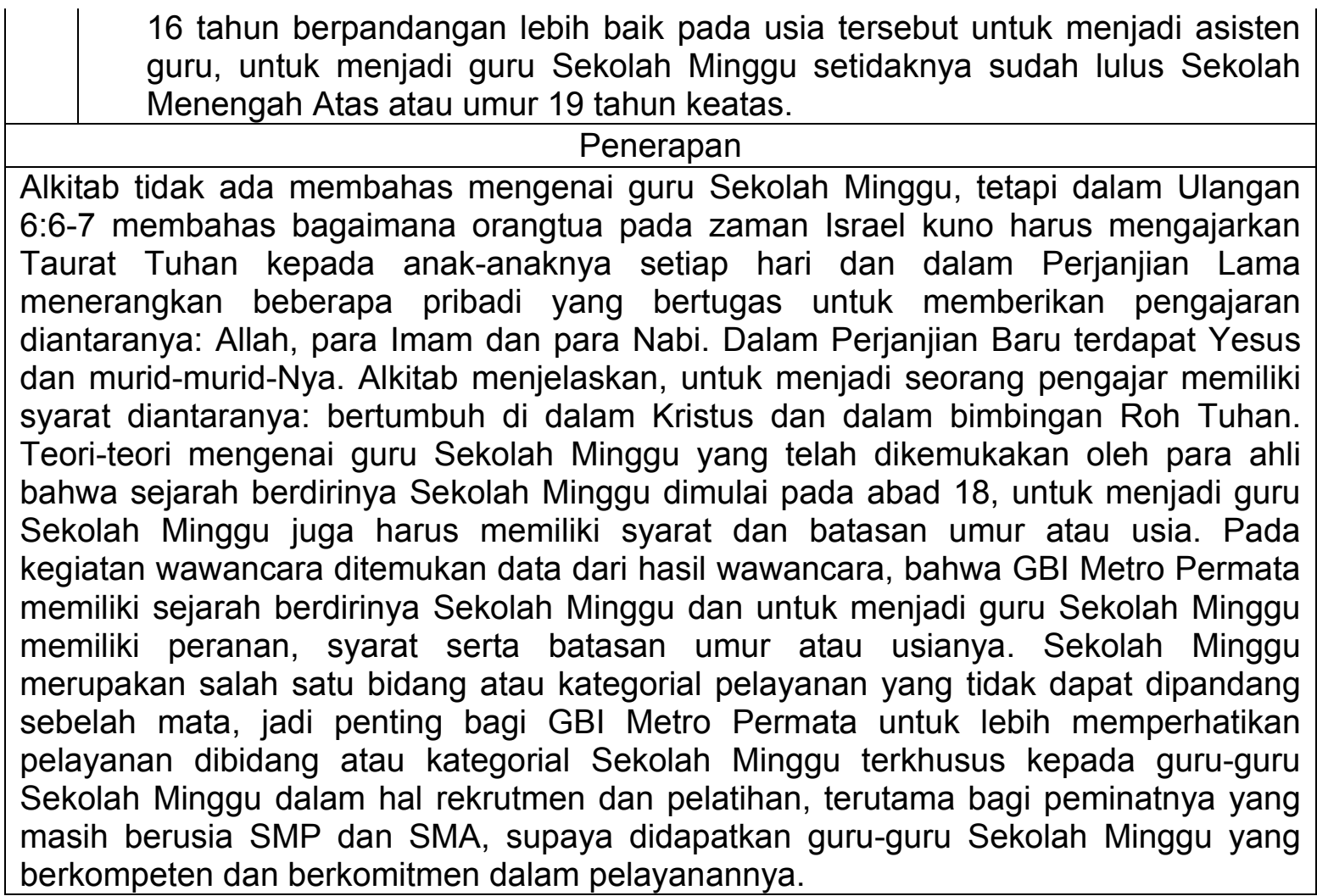

\section{Pembahasan}

Rekrutmen

Alkitab memang tidak menyebutkan kata rekrutmen, tetapi dalam Matius 9:3738 yang berisi: "maka kata-Nya kepada murid-murid-Nya: "tuaian memang banyak, tetapi pekerja sedikit. Karena itu mintalah kepada tuan yang empunya tuaian, supaya la mengirimkan pekerja-pekerja untuk tuaian itu." Berdasarkan ayat tersebut, penulis meyakini jika ayat 37 dan 38 berbicara mengenai rekrutmen. Adapun langkah-langkah untuk memahami Matius 9:37-38, terpapar sebagai berikut: ${ }^{2}$

1. Tuaian. Gambaran tuaian ataupun panen sangat klasik dalam Perjanjian Lama yang berhubungan mengenai penghakiman Allah (Yes. 27:12; Yoel 4:13). Sedangkan menurut Perjanjian Baru, pada akhir sejarah Putra Manusia akan mengumpulkan gandum dalam lumbungnya dan akan membakar lalang dan hal itulah yang dimaksudkan tuaian di dalam Perjanjian Baru (Mat. 13:30,40). Bila melihat Matius 9:35-36 merupakan pemandangan tentang pekerjaan Tuhan Yesus di Galilea (ay. 35) dan reaksi Tuhan Yesus ketika melihat orang banyak pada waktu la berkeliling (ay. 36). Jadi pada tahap ini, dapat diberikan kesimpulan tuaian berbicara kepada setiap orang yang ada di dunia, terutama bagi orang yang percaya maupun tidak percaya kepada Tuhan Yesus, mereka adalah tuaian dan dijadikan ladang-ladang tempat penuaian.

\footnotetext{
${ }^{2}$ Stefan Leks, Tasir Injil Matius (Yogyakarta: Kanisius, 2003), 209-211.
} 
2. Pekerja sedikit. Hal ini menunjukkan bila saat itu Yesus menjadi satu-satu-Nya pemberita Injil dan "penuai", sedangkan Matius 9:36 Yesus melihat orang banyak seperti domba yang tidak bergembala.

3. Meminta. Kata meminta disini merujuk kepada suatu kegiatan untuk mendapatkan sesuatu dan salah satu cara untuk melakukan kegiatan meminta tersebut adalah berdoa kepada sang empunya tuaian yakni Tuhan Yesus Kristus. Berdasarkan pengertian ini, hanya melalui doa manusia dapat mengakui, bahwa pemilik tuaian adalah Tuhan Yesus Kristus dan Tuhan Yesus Kristus membutuhkan manusia sebagai pekerja dalam melaksanakan tugas pekerjaan-Nya di ladang-Nya.

4. Mengirimkan. Sama seperti pembahasan sebelumnya, kata mengirimkan merujuk kepada kegiatan untuk pemberian kepada sesuatu. ${ }^{3}$ Berdasarkan pengertian ini, jelas mengacu kepada orang-orang yang siap sedia untuk menjadi utusan dalam melaksanakan tugas sebagai pekerja, untuk melakukan pekerjaan-pekerjaan penuaian di ladang-Nya.

Jadi sejak kedatangan Yesus Kristus untuk pertama kali ke dalam dunia dan berdasarkan Matius 9:37-38, pada saat itu hanya Yesus-lah satu-satunya pemberita Injil dan "penuai", kemudian la memberitahukan kepada murid-muridNya, jika murid-murid harus meminta atau berdoa kepada Tuhan yang empunya tuaian, supaya mengirimkan pekerja-pekerja untuk melakukan pekerjaan tuain itu di ladangNya; ${ }^{4}$ sehingga dengan demikian, organisasi gereja tidak dapat melakukan kegiatan mencari pekerja-pekerja atau rekrutmen dengan sendirinya, tanpa meminta langsung atau berdoa kepada Tuhan yang merupakan sang empunya tuaian itu agar la sendiri yang akan mengirimkan para pekerja-pekerja yang akan melakukan pekerjaan di ladangNya.

Berdasarkan penjabaran yang telah dilakukan oleh penulis mengenai Matius 9:37-38, maka penulis melihat ada suatu kegiatan rekrutmen yang terjadi dalam mencari pekerja-pekerja tuaian di ladangNya. Jika hal tersebut dikaitkan dengan Matius 10:1-4, maka ada suatu langkah untuk melakukan rekrutmen. Seperti ketika Yesus "memanggil" kedua belas muridNya (10:1). Kata "memanggil"

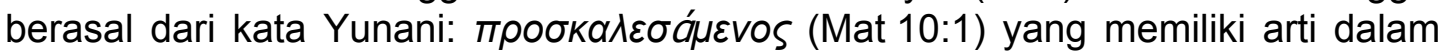
bahasa Inggris to summon, to call, dan dalam bahasa Indonesia berarti untuk memanggil. Bob Yandian memberikan pengertian mengenai panggilan "if you have been born again, you have a calling, because a calling is simply the will of God for your life. It is the work God wants you to accomplish during the time you are on earth". ${ }^{5}$ Bila demikian, jelas setiap orang percaya memiliki panggilan di dalam dirinya, tetapi panggilan akan terpenuhi tergantung beberapa faktor. Pertama, harus mengakui panggilan itu, dan kedua, harus menerima panggilan tersebut. Salah satu cara agar dapat menerima panggilan atau mengetahui kehendak Tuhan adalah berdoa kepada Tuhan. Sudah menjadi tugas organisasi gereja untuk mengetahui panggilan dari setiap jemaatnya, karena sumber rekrutmen gereja berasal dari sumber daya manusia organisasi gereja tersebut, yakni para jemaat. Tergantung apakah organisasi gereja tersebut mau

\footnotetext{
${ }^{3}$ Tim Penyusun, Kamus Besar Bahasa Indonesia (Jakarta: Balai Pustaka, 2000), 505.

${ }^{4}$ J.J. de Heer, Injil Matius (Jakarta: BPK Gunung Mulia, 2003), 177.

${ }^{5}$ Bob Yandian, Calling and Separation (Oklahoma: Harrison House Incorporated, 2013), 14.
} 
memberdayakan setiap sumber daya manusia yang dimiliki atau tidak. Terkait pada teori umum yang telah dijabarkan oleh penulis sebelumnya, bahwa disebuah organisasi harus memiliki kualifikasi dan proses dalam melakukan rekrutmen, begitu juga halnya di dalam sebuah gereja yang sudah semestinya memiliki kualifikasi dan proses dalam melakukan rekrutmen.

Kualifikasi Rekrutmen

Pembahasan sebelumnya berdasarkan pandangan umum mengenai adanya kualifikasi dalam melakukan rekrutmen pada sebuah organisasi atau perusahaan, maka sekarang penulis akan membahas padangan Alkitab mengenai kualifikasi dalam melakukan rekrutmen pengerja, berdasarkan 1 Timotius 3:1-7 yang akan dipaparkan sebagai berikut: Benarlah perkataan ini: "Orang yang menghendaki jabatan penilik jemaat menginginkan pekerjaan yang indah." (1 Tim. 3:1).

Ucapan "benarlah perkataan ini" sudah terpakai terlebih dahulu (1 Tim. 1:15) dengan kata lain, ucapan ini dijamin kebenarannya oleh Paulus. ${ }^{6}$ Kata "penilik jemaat” berakar kata dari bahasa Yunani yakni: ćm í́кото (episkopos), jabatan ini sama dengan "penatua" (Kis. 20:17, 28; Tit. 1:5,7). Tugas dari keduanya adalah mengawasi pertemuan jemaat dan mengurus jemaat Allah. Kata "pekerjaan" merujuk kepada suatu jabatan yang akan ditempati oleh seseorang yang akan bekerja di ladang-Nya. Jabatan itu harus diberikan berdasarkan "panggilan" dari Tuhan. Setiap penilik jemaat harus merasa yakin telah dipanggil oleh Tuhan untuk melakukan perkerjaan di ladang-Nya. Karena itu penilik jemaat haruslah seorang yang tak bercacat, suami dari satu isteri, dapat menahan diri, bijaksana, sopan, suka memberi tumpangan, cakap mengajar orang, (1 Tim. 3:2) bukan peminum, bukan pemarah melainkan peramah, pendamai, bukan hamba uang (1 Tim. 3:3) seorang kepala keluarga yang baik, disegani dan dihormati oleh anak-anaknya (1 Tim. 3:4) Jikalau seorang tidak tahu mengepalai keluarganya sendiri, bagaimanakah ia dapat mengurus Jemaat Allah? (1 Tim. 3:5). Janganlah ia seorang yang baru bertobat, agar jangan ia menjadi sombong dan kena hukuman Iblis. (1 Tim. 3:6) Hendaklah ia juga mempunyai nama baik di luar jemaat, agar jangan ia digugat orang dan jatuh ke dalam jerat Iblis (1 Tim. 3:7). Surat 1 Timotius 3:2-7 merupakan titik fokus kualifikasi dalam rekrutmen. Jika pada penjelasan sebelumnya penilik jemaat yang memiliki tugas untuk mengawasi pertemuan jemaat dan mengurus jemaat Allah, berdasarkan panggilan yang telah diterima dari Tuhan untuk melakukan perkerjaan di ladang-Nya. Maka untuk menjadi seorang penilik jemaat yang siap dipekerjakan di ladang-Nya memiliki beberapa kualifikasi, diantaranya: seorang tak bercacat, suami dari satu istri, dapat menahan diri, bijaksana, sopan, suka memberi tumpangan, cakap mengajar orang, bukan peminum, bukan pemarah melainkan peramah, pendamai, bukan hamba uang, seorang kepala keluarga yang baik, disegani dan dihormati oleh anak-anaknya, bukan seorang petobat baru, dan mempunyai nama baik diluar gereja. Dalam 1 Timotius 3:2-7 merupakan kualifikasi rekrutmen untuk seorang calon pejabat atau pengerja dalam jemaat. Jika seorang tidak memenuhi dari setiap kualifikasi rekrutmen yang telah dipaparkan, janganlah orang tersebut

\footnotetext{
${ }^{6}$ R. Budiman, Tafsiran Alkitab: Surat-surat Pastoral 1 dan 2 Timotius dan Titus (Jakarta: BPK Gunung Mulia, 2008), 26.
} 
dipilih. Setiap kualifikasi rekrutmen yang telah dijabarkan memang berat, tetapi haruslah diingat bahwa Tuhan menghendaki jemaat-Nya suci (1 Ptr. 1:14-16).

Ada beberapa langkah dalam proses perekrutan murid-murid Yesus sampai kepada pengutusan yang terpapar dalam Matius 28:19-20. Langkah-langkah proses perekrutan dimulai dari adanya panggilan Ilahi di dalam diri calon pengerja, setelah itu dilakukan pembaptisan sebagai tanda bahwa orang tersebut telah menerima Yesus Kristus dan lahir baru, lalu dilakukan pengajaran sebelum orang tersebut mengemban tugas sebagai pekerja penuai tuaian di landangNya, tidak berhenti sampai disitu, tugas selanjutnya ialah memberikan kesempatan kepada calon pengerja untuk melakukan setiap pengajaran yang telah diterima, dan langkah terakhir ialah organisasi gereja melakukan penempatan tugas bagi para calon pengerja sesuai dengan panggilan yang telah diterima.

Guru Sekolah Minggu

Kata guru sekolah minggu tidak terdapat di dalam Alkitab. Robert Raikes memprakarsai suatu rencana untuk mendidik anak miskin pada hari minggu, yang di ejawantahkan dalam lembaga sekolah Minggu. Tindakan Raikes di tahun 1780 mengawali terjadinya sekolah minggu. ${ }^{7}$ Berdasarkan istilah definisi sebelumnya, memberikan pengertian bahwa guru adalah pengajar yang memiliki mutu atau kualitas serta kepandaian atau keahlian khusus dalam mengajar firman Tuhan di Sekolah Minggu. Penulis melakukan pembahasan berdasarkan ajaran dan didikan yang dilakukan oleh para orangtua di bangsa Yahudi, yang melakukan ajaran dan didikan kepada anak-anak mereka (lihat UI. 6:6-7). "Apa yang kuperintahkan kepadamu pada hari ini haruslah engkau perhatikan (UI. 6:6)"

Kata "kuperintahkan" disini mengacu kepada hukum Taurat Musa yang mengungkapkan pengharapan Allah atas perilaku moral dan rohani Israel, pedoman-pedoman yang Allah berikan kepada Israel untuk memampukan orang Israel menjalani kehidupan yang dimaksudkan oleh pencipta-Nya. Kata "perhatikan" ingin menunjukkan jika perkataan tersebut penting. Jadi dalam Ulangan 6:6, merupakan sebuah perintah yang datangnya dari Allah dan memerlukan perhatian yang lebih.

"haruslah engkau mengajarkannya berulang-ulang kepada anak-anakmu dan membicarakannya apabila engkau duduk di rumahmu, apabila engkau sedang dalam perjalanan, apabila engkau berbaring dan apabila engkau bangun. (UI. 6:7). Ini akan menjadi konsentrasi pembahasan yang akan dilakukan oleh penulis. Dalam ayat ini, merupakan lanjutan dari pembahasan ayat sebelumnya (ay. 6). Kata "haruslah" merupakan sebuah kata keterangan untuk menunjukkan jika perkataan atau perintah itu patut atau wajib untuk dilakukan. Kata "mengajarkannya" berarti melakukan sebuah kegiatan untuk memperlengkapi seseorang dengan wawasan dan pengetahuan. Sedangkan kata "mengajarkan" memiliki pengertian dan pemahaman yang berbeda, antara pendidikan pada zaman Israel kuno dan pendidikan dunia modern. Baik dalam peristiwa-peristiwa, aktivitas-aktivitas dan gambaran-gambaran yang menjadi ciri pendidikan pada zamannya. Jika pendidikan zaman Israel Kuno dapat dikatakan pendidikan enkultural yang disengaja atau pendidikan yang bersifat nonformal. Pada zaman pendidikan Israel kuno, terdapat petunjuk-petunjuk akan adanya sebuah sekolah

\footnotetext{
${ }^{7}$ Robert R. Boehlke, Sejarah Perkembangan Pikiran dan Praktek PAK (Jakarta: BPK Gunung Mulia, 2009), 384.
} 
ditengah tempat ibadah, dengan adanya pendidikan dapat diindikasikan sebagai pengajaran yang disengaja.

Dalam pendidikan dunia modern, sentra pendidikan formal yang dipresumsikan adalah sekolah, maka di dalam dunia Israel kuno sentra normatif pendidikan adalah rumah. Dalam Ulangan 6:20-25 orangtua harus siap untuk menjawab setiap pertanyaan anak-anak mereka mengenai makna dari Taurat dan asal-usulnya. Ruang lingkup pendidikan agama Yahudi, bukanlah suatu usaha untuk membekali pengetahuan dalam sehari, tetapi pendidikan agama Yahudi memiliki bagian inti yakni dari pengajaran sehari-hari yang lazim dilakukan, hal ini terkait dengan kata "berulang-ulang". Bila demikian untuk memenuhi syarat pendidikan orang Israel kuno, maka orangtua diwajibkan untuk menjadi pelajar seumur hidup. Jadi, kata "haruslah engkau mengajarkannya berulang-ulang kepada anak-anakmu .... (Ul. 6:7) merupakan salah satu cara utama untuk mengungkapkan kasih kepada Allah (UI. 6:5) dan pemeliharan firman Tuhan secara berkesinambungan (ay. 8-9).

Pendidikan yang diajarkan pada zaman Israel kuno tidak dapat berjalan dengan sendirinya, maka memerlukan pengajar. Alkitab sendiri memberikan gambaran mengenai pengajar-pengajar, diantaranya; Allah, la adalah sang pengajar agung dari Alkitab, seluruh alur Alkitab bisa dipandang sebagai ajaran Allah. Ajaran-Nya yang diajarkan dalam bentuk ketetapan-ketetapan, titah-titah dan perintah-perintah yang tersimpan dalam Kitab Taurat (Kel. 20:1-17; UI. 5:1-21; 1:26; 9:23; 1 Sam. 12:14); Imam Lewi dan para Nabi. Antara para pengajar Perjanjian Lama, selain menjadi tugas bagi para Nabi untuk melakukan pengajaran, imam Lewi merupakan salah satu contoh pengajar bagi bangsa Israel. Tugas imam Lewi tidak hanya memberikan bantuan di dalam pekerjaan keimaman di Bait Allah, sebagian dari panggilan imam Lewi adalah membantu menumbuhkan dan memelihara pengetahuan tentang Taurat (UI. 33:9-11) dan terkadang orang-orang Lewi terlihat sebagai pengajar keliling (2 Taw. 17:7-9). Para Nabi bisa dikatakan sebagai pengajar-pengajar pada zaman Perjanjian Lama, hal ini dikarenakan para Nabi telah mendapat pembelajaran di kelas-kelas bagi para Nabi.

Selama masa kerajaan, terdapat institusi atau sekolah untuk nabi atau versi dalam bahasa Inggrisnya school of Prophets. Terbukti dari banyaknya nabi-nabi yang terdapat di dalam Perjanjian Lama (2 Raj. 2:15; 4:1; 4:38; 5:22; 6:1; 9:1). Yesus Kristus, tugas mengajar sangat penting di dalam dunia ini, hal itu dapat dipahami dari kehidupan dan pelayanan Yesus Kristus, Allah yang menjadi manusia. la datang ke dunia untuk memperkenalkan Allah melalui kegiatan mengajar, berkhotbah, mengadakan mukjizat dan mendemonstrasikan teladan hidup yang benar. Injil Matius mengemukakan bahwa Yesus mengajar berdasarkan otoritas, wibawa dan kuasa. Sehingga orang yang mendengarkan pengajaran-Nya (Yunani; $\delta\llcorner\delta \alpha \kappa \eta \overline{\mathrm{e}}$ ) menjadi takjub, terpukau dan memberi respon positif (Mat. 7:28-29; 22:23; Mrk. 1:22; 6:22; 11:28; Luk. 4:32). Murid-murid, kitab Injil melaporkan, bahwa sebelum Yesus meninggalkan murid-murid-Nya, Yesus memberikan mandat penting, yaitu menjadikan semua bangsa murid-Nya (Mat. 28:19-20), dan mandat yang diberikan kepada para murid - lalu dijadikan sebagai tujuan dari pengajaran yang dilakukan oleh murid-murid-Nya untuk memimpin tiap-tiap orang kepada kesempurnaan hidup di dalam Yesus Kristus. 
Kata "pengajar" mengindikasikan kepada sesosok orang yang mengajar, dengan kata lain seorang guru. Guru memiliki pengertian orang yang pekerjaannya mengajar, ${ }^{8}$ sedangkan dalam bahasa Yunani ada beberapa sebutan untuk guru, diantaranya:

1. $\dot{\alpha} \beta \beta$ ouví atau rabbouni (Mark. 10:51), merupakan sebutan kepada Yesus sebagai guru. Makna dari sapaan ini sebagai pengakuan hormat kepada seorang yang ahli Kitab Suci, sekaligus menyatakan hubungan pribadi yang dirasakan sangat mendalam.

2. غ́тıбта́тns atau epistatē (Luk. 5:5; 8:24), merupakan sebutan yang dipergunakan bagi orang berstatus tinggi, khususnya bagi orang yang memainkan peran di dalam kepemimpinan.

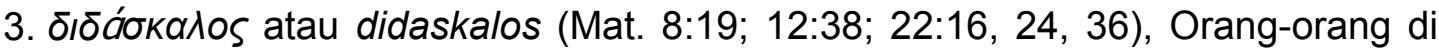
dalam Alkitab memanggilnya dengan sebutan ini, termasuk kedua belas murid, tokoh-tokoh agama Yahudi, ahli Taurat dan orang Farisi. Bahkan Yesus sendiri mengakui jika diri-Nya sebagai guru dengan sebutan didaskalos (Yoh. 13:1314, Mrk. 14:14).

Menjadi seorang pengajar atau guru, harus "memperoleh karunia" seperti pernyataan Paulus yang ada di dalam Efesus 4:11 "Dan la-lah yang memberikan baik rasul-rasul maupun nabi-nabi, baik pemberita-pemberita Injil maupun gembala-gembala dan pengajar-pengajar." Berdasarkan Efesus 4:11 ini, sudah jelas jika Tuhan yang akan memberikan jawatan-jawatan "untuk memperlengkapi orang-orang kudus bagi pekerjaan pelayanan" (Ef. 4:12) dan berdasarkan panggilan yang terdapat di dalam dirinya (ay. 4). Pada masa gereja mula-mula, benyak bermunculan guru-guru palsu, sehingga hal tersebut mendesak perlunya pengadaan pekerja-pekerja yang berkualitas dalam membina warga jemaat. Yakobus mencatat bahwa profesi guru sangat populer pada masa itu sehingga banyak orang ingin menjadi guru, tanpa mempertimbangkan peningkatan kualitas pelayanan dan hidupnya (Yak. 3:1).

Pelatihan

Penjelasan mengenai pelatihan telah dijelaskan sebelumnya, berdasarkan pandangan umum dan pandangan para ahli. Kata "pelatihan" tidak terdapat di dalam Alkitab, melainkan terdapat kata terlatih (Kej. 14:13; 1 Taw. 5:18; Kid. 3:8; Yer. 31:18; Hos. 10:11; Ibr. 5:14; 2 Pet. 2:14), dilatih (Hak. 3:2; 1 Taw. 25:7; Ibr. 12:11), melatih (Hos. 7:15; 1 Kor. 9:27), latihlah (1 Tim. 4:7) dan latihan (1 Tim. $4: 8)$, tentunya dengan pengertian dan pemahaman yang berbeda disetiap kitab dan pasalnya. Dalam pembahasan kali ini untuk menghindari terjadinya pembiasan, maka penulis akan melanjutkan pembahasan sebelumnya mengenai guru, untuk mendukung pembahasan maka penulis akan mengambil contoh dari pengajaran dan pelatihan yang dilakukan oleh Yesus Kristus kepada murid-muridNya semasa pelayanan-Nya di bumi. Metode pengajaran dan pelatihan yang dilakukan oleh Yesus dalam Injil adalah ceramah, diskusi, tanya jawab dan bercerita. Perlu ditegaskan bahwa dalam Injil, metode yang paling sering digunakan oleh Yesus saat melakukan pelatihan adalah metode cerita. Metode ini dapat dilihat dalam bentuk perumpamaan (Mrk. 4:1-20; 21-25; 26-29; 30-33).

\footnotetext{
${ }^{8}$ Tim Penyusun, Kamus Besar bahasa Indonesia, Op. Cit., 330.
} 
Sementara metode dapat diartikan sebagai "suatu cara, sikap dan prinsip untuk mencapai maksud tertentu", berikut ini beberapa metode yang digunakan Yesus dalam Injil.

Metode ceramah

Pengertian metode ceramah adalah cara belajar atau mengajar yang menekankan pemberitahuan satu arah dari pengajar kepada yang diajar. ${ }^{9}$ Metode ini digunakan oleh Yesus sebagai metode untuk mengajar orang banyak bersama murid-murid-Nya (Mrk. 13:1-2; 13:3-13; 13:14-23; 13:24-32). Melalui metode ini, Tuhan Yesus berusaha untuk menyampaikan pengetahuan mengenai firman Tuhan kepada murid-murid-Nya untuk kembali diajarkan kepada orang banyak (Mat. 28:18-20).

Metode diskusi

Metode diskusi adalah cara belajar atau mengajar yang melakukan tukar pikiran antara murid dengan guru, murid dengan murid sebagai peserta diskusi. ${ }^{10}$ Metode ini juga sering dipakai Yesus dalam mengajar. Terlebih khusus dalam Injil Matius 2:23-28; 6:30-44, Yesus melakukan pengajaran sambil berdiskusi kepada murid-murid-Nya dan tidak sering juga melakukan pengajaran kepada orang banyak.

Metode tanya jawab

Metode Tanya jawab adalah cara penyajian pelajaran dalam bentuk pertanyaan yang harus dijawab. ${ }^{11}$ Penggunaan metode ini dilakukan Yesus untuk menjadi bahan pemikiran dari pada murid-murid-Nya. Dalam Matius 8:27-30, Yesus memberikan pertanyaan kepada murid-murid-Nya, kemudian Petrus menjawab pertanyaan tersebut. Tujuan-Nya memberikan pertanyaan tersebut, untuk mengetahui jawaban mereka agar mengetahui pengetahuan mereka, kemudian dari jawaban tersebut Yesus mendidik dengan sebuah pengajaran yang benar.

Metode cerita

Bercerita adalah metode komunikasi universal yang sangat berpengaruh kepada jiwa manusia. Bahkan dalam teks kitab sucipun banyak berisi ceritacerita. $^{12}$ Yesus adalah seorang yang ahli dalam bercerita. Metode bercerita yang dilakukan Yesus berbentuk perumpamaan-perumpamaan, sehingga kata perumpamaan memiliki pengertian perbandingan; ibarat; peribahasa yang berupa perbandingan. Ada beberapa perumpamaan-perumpamaan yang digunakan Yesus berupa kisah nyata, perumpamaan berupa cerita maupun illustrasi.

\footnotetext{
${ }^{9}$ W. Gulo, Strategi Belajar Mengajar (Jakarta: Grasindo, 2005), 142.

${ }^{10}$ Dewi Salma Prawiradilaga, dkk., Mozaik Teknologi Pendidikan (Jakarta: Perpustakaan Nasional, 2016), 115.

${ }^{11}$ H Darmadi, Pengembangan Model Metode Pembelajaran (Yogyakarta: CV Budi Utama, 2012), 200.

${ }^{12}$ Rosdianah, dkk., Dongeng Cerita Anak (Makassar: Aksara Timur, 2018), 3.
} 


\section{Kesimpulan}

Matius 9:37-38 diyakini sebagai sebuah tanda bahwa diperlukannya tindakan untuk melakukan kegiatan rekrutmen. Pada teori-teori mengenai rekrutmen harus memiliki peranan, tujuan, sumber, kualifikasi dan proses dalam melakukan rekrutmen. Alkitab sendiri menjelaskan bahwa dalam melakukan kegiatan rekrutmen ada kualifikasinya (1 Tim. 3:1-7) dan prosesnya (Mat. 28:19-20), maka dari hasil wawancara yang telah dilakukan sebelumnya oleh penulis kepada para narasumber, didapatkan data bahwa dalam hal melakukan rekrutmen di GBI Metro Permata ada peranan, tujuan, sumber, kualifikasi dan proses rekrutmennya sendiri, sehingga penting bagi GBI Metro Permata untuk lebih memperhatikan kegiatan dalam melakukan rekrutmennya guna mencari pengerja yang berkompeten dan berkomitmen, terkhusus dibidang atau kategorial Sekolah Minggu.

Penting bagi sebuah organisasi terutama sebuah gereja untuk memiliki program pelatihan bagi setiap bidang atau kategorial pelayanannya, terlebih dalam Alkitab terdapat kata terlatih (Kej. 14:13; 1 Taw. 5:18; Kid. 3:8; Yer. 31:18; Hos. 10:11; Ibr. 5:14; 2 Pet. 2:14), dilatih (Hak. 3:2; 1 Taw. 25:7; Ibr. 12:11), melatih (Hos. 7:15; 1 Kor. 9:27), latihlah (1 Tim. 4:7) dan latihan (1 Tim. 4:8). Yesus sendiri melatih murid-murid-Nya dengan mengunakan beberapa metode seperti: metode ceramah, metode diskusi, metode tanya-jawab dan metode cerita. Teori-teori mengenai pelatihan yang telah dikemukakan oleh para ahli memberikan beberapa pemahaman seperti: tujuan, manfaat dan teknik dari pelatihan yang akan dilakukan oleh suatu perusahaan atau organisasi. Hasil dari kegiatan wawancara yang telah dilakukan oleh penulis kepada para nara sumber ditemukan data bahwa GBI Metro Permata melakukan kegiatan pelatihan bagi setiap pengerjanya terkhusus bidang atau kategorial Sekolah Minggu dengan tujuan, manfaat dan teknik pelatihan yang telah dilakukan dan yang telah diterima.

Alkitab tidak ada membahas mengenai guru Sekolah Minggu, tetapi dalam Ulangan 6:6-7 membahas bagaimana orangtua pada zaman Israel kuno harus mengajarkan taurat Tuhan kepada anak-anaknya setiap hari dan dalam Perjanjian Lama menerangkan beberapa pribadi yang bertugas untuk memberikan pengajaran diantaranya: Allah, para Imam dan para Nabi. Sedangkan dalam Perjanjian Baru terdapat Yesus dan murid-murid-Nya. Alkitab menjelaskan bahwa untuk menjadi seorang pengajar memiliki syarat diantaranya: bertumbuh di dalam Kristus dan dalam bimbingan Roh Tuhan. Teori-teori mengenai guru Sekolah Minggu yang telah dikemukakan oleh para ahli bahwa sejarah berdirinya Sekolah Minggu dimulai pada abad 18, untuk menjadi guru Sekolah Minggu juga harus memiliki syarat dan batasan umur. Pada kegiatan wawancara ditemukan data dari hasil wawancara, bahwa GBI Metro Permata memiliki sejarah berdirinya Sekolah Minggu dan untuk menjadi guru Sekolah Minggu memiliki peranan, syarat serta batasan umur atau usianya. Sekolah Minggu merupakan salah satu bidang atau kategorial pelayanan yang tidak dapat dipandang sebelah mata, jadi penting bagi GBI Metro Permata untuk lebih memperhatikan pelayanan dibidang atau kategorial Sekolah Minggu terkhusus kepada guru-guru Sekolah Minggu dalam hal rekrutmen dan pelatihannya terutama bagi peminatnya yang masih berusia SMP dan SMA, supaya didapatkan guru-guru Sekolah Minggu yang berkompeten dan berkomitmen dalam pelayanannya. 


\section{Kepustakaan}

Budiman, R. Tafsiran Alkitab: Surat-surat Pastoral 1dan 2 Timotius dan Titus. Jakarta: BPK Gunung Mulia, 2008.

Boehlke, Robert R. Sejarah Perkembangan Pikiran dan Praktek PAK. Jakarta: BPK Gunung ulia, 2009.

de Heer, J.J. Injil Matius. Jakarta: BPK Gunung Mulia, 2003.

Darmadi, H. Pengembangan Model Metode Pembelajaran. Yogyakarta: CV Budi Utama, 2012.

Gulo,W. Strategi Belajar Mengajar. Jakarta: Grasindo, 2005.

Leks, Stefan. Tasir Injil Matius. Yogyakarta: Kanisius, 2003.

Moleong, Lexy J. Penelitian Kualitatif. Bandung: Alfabeta, 2000.

Prawiradilaga, Dewi Salma, dkk. Mozaik Teknologi Pendidikan. Jakarta: Perpustakaan Nasional, 2016.

Rosdianah, dkk. Dongeng Cerita Anak. Makassar: Aksara Timur, 2018.

Tim Penyusun. Kamus Besar bahasa Indonesia. Jakarta: Balai Pustaka, 2000.

Yandian, Bob. Calling and Separation. Oklahoma: Harrison House Incorporated, 2013. 